\title{
人エリーフ周辺の流れと海藻群集の関係 RELATION BETWEEN WAVE-INDUCED CURRENT AND ALGAE COMMUNITY ON ARTIFICIAL REEF
}

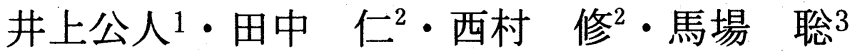 \\ Kimihito INOUE, Hitoshi TANAKA, Osamu NISHIMURA and Satoshi BABA \\ 1正会員 工修 国際航業株式会社 水域環境部（广983-0852 仙台市宮城野区榴岡 5 丁目 1 番 23 号） \\ 2 正会員 工博 東北大学教授 工学研究科土木工学専攻（テ890-8579 仙台市青葉区荒巻字青葉 06 ） \\ 3 正会員＼cjkstart岩手県大船渡地方振興局（广029-2502 岩手県気仙郡住田町下有田字中上 333 ）
}

\begin{abstract}
In recent years, the social demand toward ecological aspect of coastal area has been increasing. However, very little things have been known about the relationship between ecosystem and coastal environment. The objective of the present study is to investigate the transition of algae community on artificial reefs after construction, and the relationship between algae community on artificial reefs and intensity of wave-induced current around artificial reefs is discussed. It is concluded that the algae community on the artificial reefs on Takada Coast is influenced by the intensity of the wave-induced current around the artificial reef. Thus it might be possible to construct a naturefriendly artificial reef by using the relationship between algae community and wave-induced current revealed herein.
\end{abstract}

Key Words : artificial reef, wave-induced current, ecosystem, algae

\section{1. はじめに}

これまで我が国における海岸保全施設の建設にあたっ ては、防災を主な目的として事業等が進められてきた。 しかし、近年の内湾や沿岸域を取り巻く社会的状況の変 化は大きく、良好な海岸環境および生態系の保全に対す る要望が増大しており、波浪の低减などの防災機能や海 岸等への良好なアクセスなどの親水機能に加え、自然生 態系と共生できる自然共生型の版設整備が望まれている。 よって、今後海岸等に設置する施設については、施設の 設置が生物環境にどの程度影響するのか、正確な予測が 望まれるところであるが、海藻の植生についても生息域 の環境条件によって変化し、同一地域においても地形や 着生基質の違いなどによって、異なる分布がみられるな ど、現段階で予測を行うことは難しい状況にある。

このような背景の中で、筆者ら ${ }^{1)}$ は先の研究において 生態系の基礎を支えている海藻に着目し、人エリーフと 海藻の出現、遷移及び定着について検討を行った結果、 人エリーフが海藻の生息場として有効であることが確認 された。また、海藻の分布が人エリーフ及びその周辺に おける流れに影響されている可能性について言及した。

そこで、本研究では人エリーフに生息する海藻に着目 し、現地調査を実施して、人工リーフ設置に伴う海藻の
群落形成について整理した。また、人エリーフ周辺の流 れについて数值モデルを用いた計算を実施し、流れと海 藻の群落形成の関係について検討を行った。

\section{2. 調查場所の概要}

調査は岩手県の南部に位置する高田海岸を対象に実施 した。調查位置を図-1に示す。本海岸は陸前高田市に位 真し、日本百景にも数えられる白砂青松の風光明媚な海 岸である。近年、本海岸は侵食が問題となり海岸の侵食 防止に加え、良好な景観の保全を目的として人工リーフ が設置されている。人工リーフの平面配置を図-2に示す が、堤長が各 $400 \mathrm{~m}$ であり隣接する人エリーフとの開口 幅は $100 \mathrm{~m}$ である。施工は平成 2 年度から 2 号リーフの 東側より天端幅を暫定の $60 \mathrm{~m}$ で施工が進められており、 平成 5 年度には 1 号リーフが実施され、現在は 3 号リー

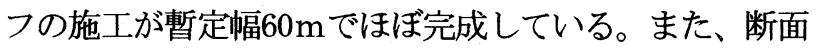
形状の計画値については、図-3に示すとおり天端高が T.P. $-2.90 \mathrm{~m}$ であり、天端幅が $120 \mathrm{~m}$ 、法勾配は $1: 3$ と なっており、堤体は自然石で被覆されている。 

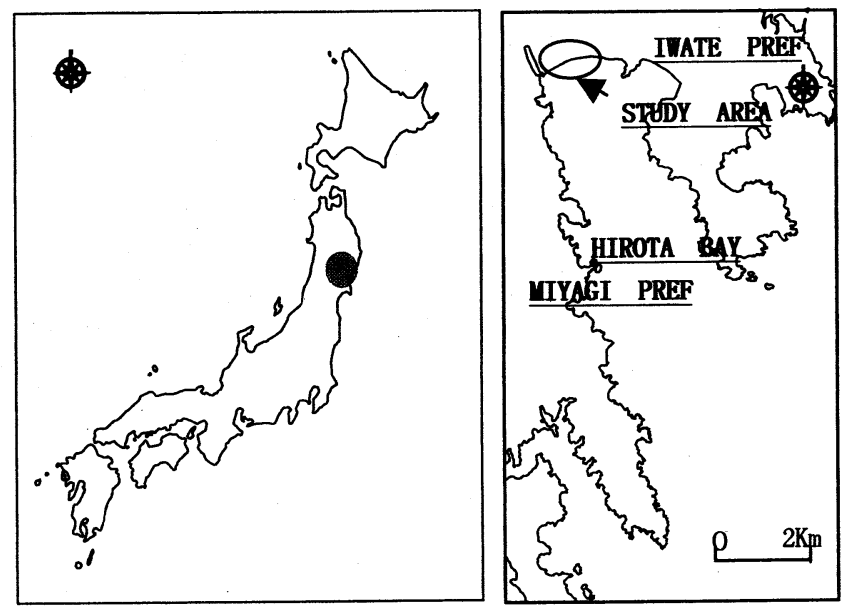

图-1現地調查位置図

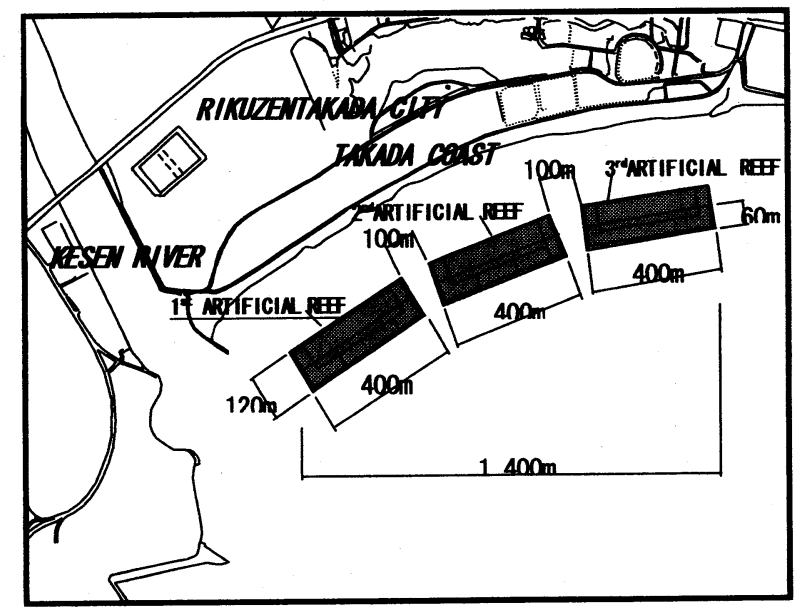

図-2人エリーフ平面配置図

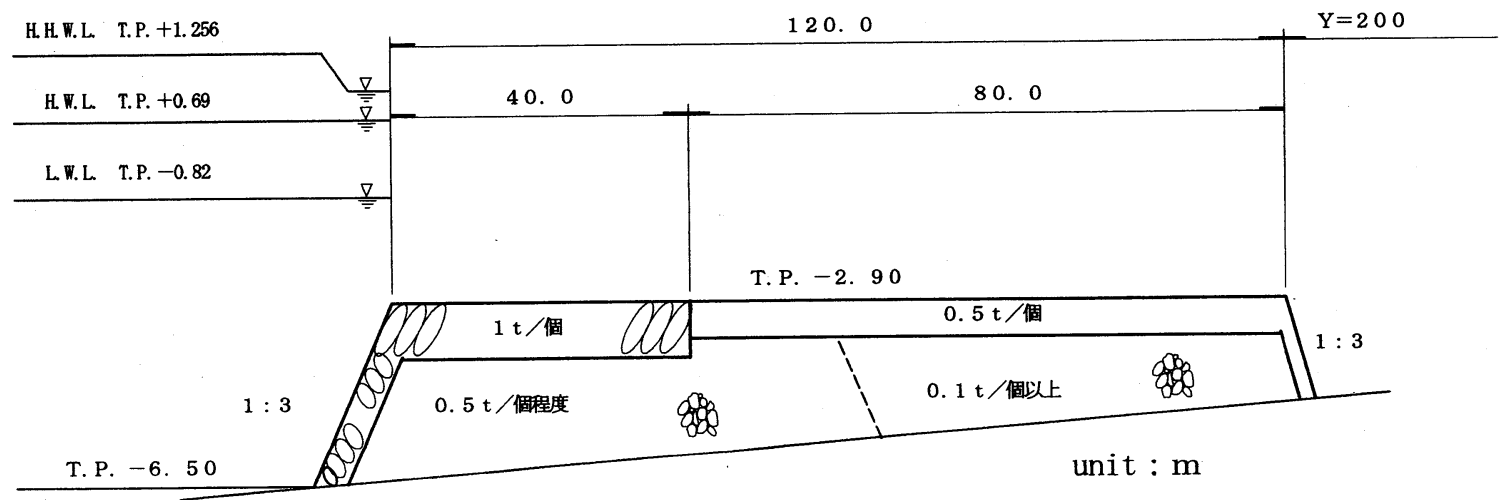

図-3 人エリーフ断面図

\section{3. 調查方法}

\section{(1) 調查測点}

調査は $1 \sim 3$ 号リーフを対象に実施し、調査測点は 図-4に示すとおり、人エリーフ上における海藻の分布状 況を把握するために、人工リーフの縦断方向に 6 測線設 定し、測線毎に横断方向に 7 測点配置した。

調査は全部で 5 回実施し、第 1 回調査から第 4 回調査 までは 3 号リーフの施工が実施されていたことから、1 号、2号リーフを対象に全28測点で、第 5 回調査では 1 〜 3号リーフを対象に全42測点で調査を実施した。

\section{（2）調查期間}

調査は1995年 1 月から 2001 年の 2 月までの 6 年間に 1998年、2000年を除く年 1 回の調査を実施し、全体で計 5 回の調查を実施した。また、調査は $1 \sim 2$ 月の冬季に 実施した。なお、調查した各測点の基質（自然石）は人 エリーフの施工の関係から、水中での放置期間が異なる ため、各調查測点と基質の施工年月日（放置期間）につ
いても考慮に入れながら調査を実施した。

\section{（3）調査内容および方法}

潜水観察は海岸域生物環境調査マニュアル゚゙にらい、 塩化ビニールパイプで作成した正方形 $1 \mathrm{~m} \times 1 \mathrm{~m}$ のコド ラートを用いて、枠内に確認された海藻および付着動物 の種別ごとに、 $1 \mathrm{~m}^{2}$ あたりに出現する海藻の被度（\%) を観察した。また、被度の観察の際、海藻が重なって分 布している場合は、それぞれの海藻の重複部分も被度と して考慮に入れた。なお、海藻の種同定には新崎ら ${ }^{3)} に$ ならい実施した。

\section{4. 解析および考察}

\section{（1）出現海藻の種類と着生状況}

本調査海域に出現した海藻は緑藻が 7 種、褐藻が 16 種、 紅藻が40種となっており、基質設置後、半年以内の箇所 では珪藻綱が全面に着生していた。その後、基質の設置 期間の増加に伴って、珪藻綱に加え緑藻綱のアオノリ属 


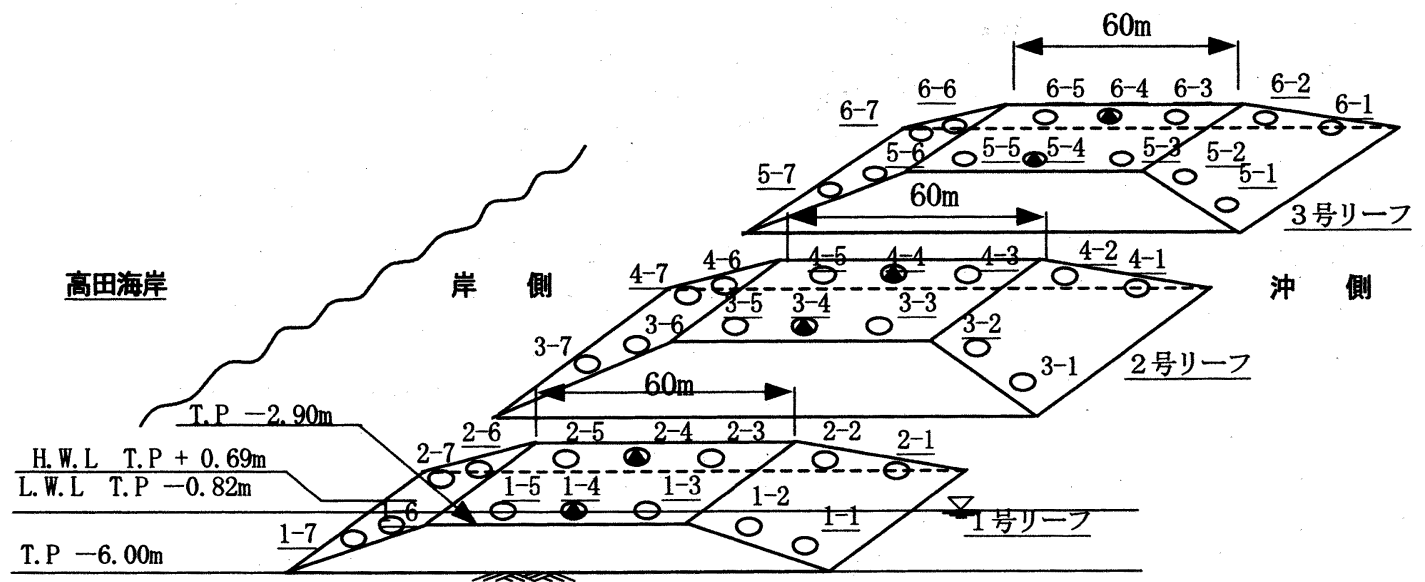

図-4 調查測点位置図 unit : m

やアオサ属、1 年生小型海藻のイギス科などがみられる ようになり、設置期間が 4 年程度を経過した測点では 1 年生大型のワカメ、多年生小型のツノマタ、サビ覀科、 多年生大型のアラメなどが繁茂する植生へと変化してい た。

ここで、片田ら゙)によれば、新しい基盤には、はじめ 付着珪藻類が全面に繁茂し、その後にアオノリ、アオサ 類の短命な緑藻類が着生し、次に、 1 年生小型海藻と直 立石灰藻がみられるようになり、1 年生の大型海藻、多 年生大型海藻の順に優占群が遷移すると述べている。

本調查測点でみられた優占種交代の経過は、この遷移 過程とよく一致していた。しかし、基質設置後 4 年程度 経過した区域において付着状況をみると、大型海藻のア ラメが広く分布する測点や、サビ亜科、イワノカワ科な どの多年生小型海藻が広く覆っている測点など、基質設 置後 4 年程度経過し、生態系の変化が安定したと考えら れる測点間で海藻の群集を構成している種に違いがみら れ、この相の違いが人工リーフ上の流速に関係している ものと考えられた。

そこで、以下に人工リーフおよび周辺区域における流 れと海藻の出現状況の関係について検討を行った。

\section{（2）人エリーフ周辺の流れの検討}

人工リーフ周辺における流れの状況を把握するため、 数值モデルを用いて人工リーフ及びその周辺区域におけ る平均流速の再現計算を実施した。まず、当該地区の物 理環境を検討するため、下式に示すエネルギー平衡方程 式を基礎式とした波浪場の計算を実施した。

$$
\left.\begin{array}{c}
\frac{\partial}{\partial x}\left(S V_{x}\right)+\frac{\partial}{\partial y}\left(s V_{y}\right)+\frac{\partial}{\partial \theta}\left(s V_{\theta}\right)=0 \\
V_{x}=C_{g} \cos \theta \\
V_{y}=C_{g} \sin \theta \\
V_{\theta}=\frac{C_{g}}{C}\left(\frac{\partial C}{\partial x} \sin \theta-\frac{\partial C}{\partial y} \cos \theta\right)
\end{array}\right\}
$$

ここで、 $S$ : 方向スペクトル、 $C:$ 波速、 $C_{g}$ : 波の

群速度、 $x$ : 岸沖方向の座標、 $y$ : 沿岸方向の座標、

$\theta: x$ 軸となす波向角を示す。

なお、上式で計算される波高には砕波の影響を考慮し ていないため、合田の砕波指標5)を用いて水深に対応し た研波限界波高を求め、その位置での波高が砕波限界波 高より大きくならないようにして砕波を考慮した。

次に、海浜流の計算を実施した。基礎式は平均流に関 する連続式と外力としてラディエーションストレス項を 加えた運動量の保存式からなっている。

$$
\left.\begin{array}{l}
\frac{\partial \eta}{\partial t}+\frac{\partial[(h+\eta) u]}{\partial x}+\frac{\partial[(h+\eta) v]}{\partial y}=0 \\
\frac{\partial u}{\partial}+u \frac{\partial u}{\partial x}+v \frac{\partial u}{\partial y}+F_{x}-M_{x}+R_{x}+g \frac{\partial \eta}{\partial x}=0 \\
\frac{\partial v}{\partial t}+u \frac{\partial v}{\partial x}+v \frac{\partial v}{\partial y}+F_{y}-M_{y}+R_{y}+g \frac{\partial \eta}{\partial y}=0
\end{array}\right\}
$$

ここで、 $\eta$ : 静水面からの平均水位の高さ、 $h:$ : 静水 時の水深、 $u, v$ : 流れの $x, y$ 成分、 $F_{x}, F_{y}$ : 底面摩擦 項、 $M_{x}, M_{y}$ : 水平拡散項、 $R_{x}, R_{y}$ : ラディエーショ ンストレス項、 $g$ : 重力加速度 である。なお、底面摩 擦項については、西村6)にならい波による水粒子の軌道 運動に伴う底面の摩擦を次のように与えている。

$$
\begin{array}{r}
F_{x}=\frac{C_{f}}{h+\eta}\left\{\left(W+\frac{w_{b}^{2}}{W} \cos ^{2} \theta\right) u+\frac{w_{b}^{2}}{W}(\sin \theta \cos \theta) v\right\} \\
F_{y}=\frac{C_{f}}{h+\eta}\left\{\frac{w_{b}^{2}}{w}(\sin \theta \cos \theta) u+\left(W+\frac{w_{b}{ }^{2}}{W} \sin ^{2} \theta\right) v\right\} \\
W=\left[\left\{u^{2}+v^{2}+w_{b}{ }^{2}+2(u \cos \theta+v \sin \theta) w_{b}\right\}^{1 / 2}+\right. \\
\\
\left.\left\{u^{2}+v^{2}+w_{b}{ }^{2}-2(u \cos \theta+v \sin \theta) w_{b}\right\}^{1 / 2}\right] / 2
\end{array}
$$


ここで式(4)の中で、 $C_{f}$ : 底面の摩擦係数、 $w_{b}$ : 底 面における波の軌道流速の最大值を示している。また、 式(3)の $M_{x}, M_{y}$ は式(5)のとおりである。

$$
\left.\begin{array}{l}
M_{x}=-\frac{\partial}{\partial x}\left(\varepsilon \frac{\partial u}{\partial x}\right)+\frac{\partial}{\partial y}\left(\varepsilon \frac{\partial u}{\partial y}\right) \\
M_{y}=-\frac{\partial}{\partial x}\left(\varepsilon \frac{\partial v}{\partial x}\right)+\frac{\partial}{\partial y}\left(\varepsilon \frac{\partial v}{\partial y}\right)
\end{array}\right\}
$$

さらに、式(5)の $\varepsilon$ は渦拡散係数であり、LonguetHiggins ${ }^{7)}$ による次式を用いた。

$$
\varepsilon=N l \sqrt{g(h+\eta)}
$$

ここに、 $N$ : 無次元パラメータ $(=0.01) 、 l$ : 離岸 距離を示す。式(3)に示すラディエーションストレス項 は、以下の示すとおりである。

$$
\left.\begin{array}{l}
\boldsymbol{R}_{x}=\frac{1}{\rho(h+\eta)}\left(\frac{\partial S_{x x}}{\partial x}+\frac{\partial S_{x y}}{\partial y}\right) \\
\boldsymbol{R}_{y}=\frac{1}{\rho(h+\eta)}\left(\frac{\partial S_{y x}}{\partial x}+\frac{\partial S_{y y}}{\partial y}\right)
\end{array}\right\}
$$

ここで、 $S_{x x}, S_{x y}, S_{y x}, S_{y y}$ はラディエーションス トレス、 $\rho$ は海水の密度であり、上記の計算結果より、 当該地区の平均流速を算出した。平均流速 $\bar{U}$ は海浜流 の $u, v$ 成分から次式で求めた。

$$
\bar{U}=\sqrt{u^{2}+v^{2}}
$$

計算条件は計算範囲を $2,580 \mathrm{~m} \times 1,350 \mathrm{~m}$ とし、計算点 間隔を $5.0 \mathrm{~m}$ とた。また、計算に用いた波浪は当該地区 近傍の江ノ島波浪観測所のデータをもとに、当該地区に
年数回程度発生する可能性がある有義波浪 $\mathrm{H}_{\mathrm{o}}{ }^{\prime}=$ $2.13 \mathrm{~m} 、 \mathrm{~T}=10.3 \mathrm{~s}$ を算出し、シミュレーション計算に用 いた。計算結果を図-5に示す。この結果より、人エリー フ上において速い流速がみられ、特に、1 号リーフ上で $20 \mathrm{~cm} / \mathrm{s}$ 程度の流速が分布していた。また、1 号リーフ背 後において河口部方向からの流入がみられ、逆に、2 号 リーフ堤内側から堤外側に向けて流出がみられた。

\section{（1）人エリーフ周辺の流れと海藻の群集構成 \\ （a）人エリーフ上に生息する海藻の群集分類}

次に、海藻の現地観察結果を用いて、調査毎に人工 リーフに生息する海藻を数種の群集に分類するため、出 現種別の被度から各調査測点の類似度を求め、群集分析 を行った。

類似度は式(9)に示すKimoto ${ }^{8)}$ のMorisitaによる修正式 C川 指数を用いた。

$$
\begin{gathered}
C \Pi=\frac{2 \sum_{i=1}^{S} n_{1 i} \cdot n_{2 i}}{\left(\sum \Pi_{1}^{2}+\sum \Pi_{2}^{2}\right) \mathrm{N}_{1} \cdot \mathrm{N}_{2}} \\
0 \leqq c \Pi \leqq 1
\end{gathered}
$$

但し、式(9)の $\sum \Pi_{1}^{2} 、 \sum \pi_{2}^{2}$ は式(10)に示すとおりであ

る。

$$
\sum \Pi_{1}^{2}=\frac{2 \sum_{i=1}^{S} n_{1 i}^{2}}{\mathrm{~N}_{1}^{2}} \cdot \sum \Pi_{2}^{2}=\frac{2 \sum_{i=1}^{S} n_{2 i}^{2}}{\mathrm{~N}_{2}^{2}}
$$

ここで、 $N_{1}, N_{2}$ : 第 1 組および第 2 組におけるサン プル総数であり、 $n_{1 i}, n_{2 i}$ : それぞれの組における第 $i$ 番 目の区分に属するサンプル数、 $S$ : 測点間の組数であ

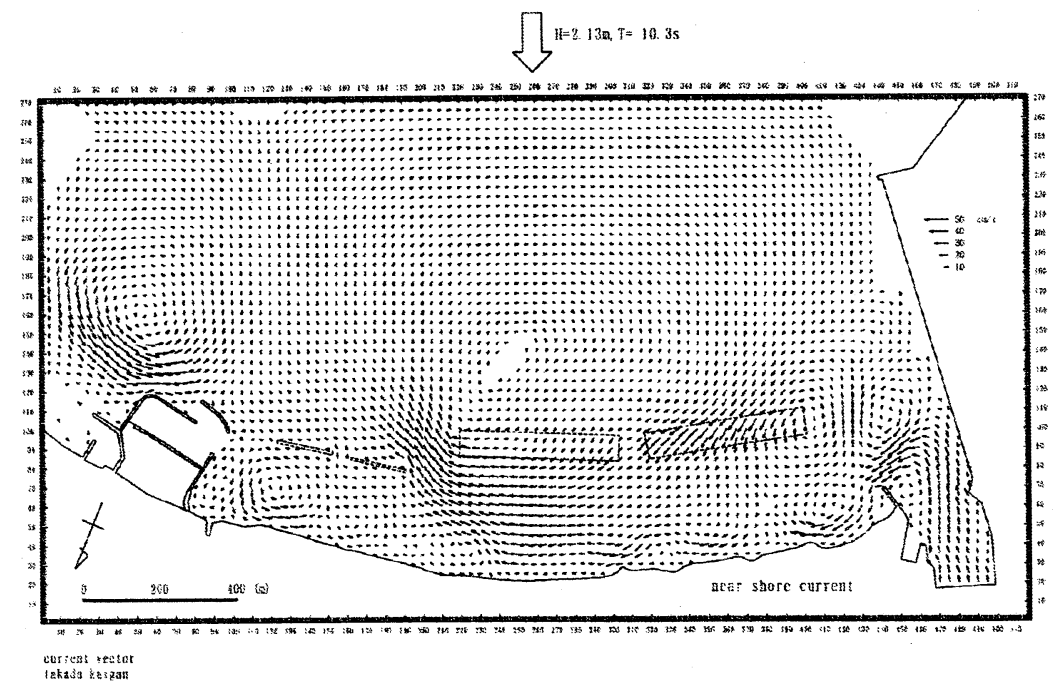

図-5 海浜流計算結果

$\left(\mathrm{H}_{0}{ }^{\prime}=2.13 \mathrm{~m}, \mathrm{~T}=10.3 \mathrm{~s} \quad\right.$ 人エリーフ 2 基設置時 $)$ 
る。

また、算出した類似度を用いてウォード法による群集 分類を行い、算出結果の 1.0 を基準に各調査測点の群集 構成種を検討した。

\section{（b）人エリーフ上の海藻群集と流れの関係}

次に、人エリーフ周辺の流れと上記に分類した海藻の 群集の関係を検討した。筆者らは先の研究1)の中で、基 質設置後 4 年程度経過すると人エリーフに生息する海藻 の遷移が安定することを示した。そこで、海藻の群集と 人エリーフ周辺の流れの関係について、施工後 4 年以上 経過している調査測点の海藻群落を対象に検討を行った。 今回実施した群集の分類より、基質設置後 4 年以上経 過している測点の群集は、全部で22の群集に分類された。 また、それら群集の構成種をみると、22群集の内19群集 がツノマタ属、サビ亜科、アカバギンナンソウ、アラメ、 イワノカワ科の 5 種により構成されており、 5 種のうち 1 種で構成されている群集や、2種あるいは 3 種で構成 される群集に分類された。そこで、上記に示す 5 種が当 該海域の主構成種として、どの流速範囲にどの海藻が群 集として生息可能か検討するため、平均流速と各海藻の 分布範囲について検討した。検討結果を図-6に示す。

この結果、サビ亜科、イワノカワ科の 2 種については 平均流速が3-30cm/sの広い範囲で群集を構成していたが、 ッノマタ、アカバギンナンソウについては、平均流速が 7-24cm/sの範囲で群集を構成しており、サビ亜科やイワ ノカワ科に比べて、ツノマタ、アカバギンナンソウの出 現範囲は若干狭くなる傾向にあった。また、アラメにつ いては $-25 \mathrm{~cm} / \mathrm{s}$ 範囲にあり、サビ亜科やイワノカワ科 のような、速い流速での出現はみられず、遅い流速域で 群集を構成していた。

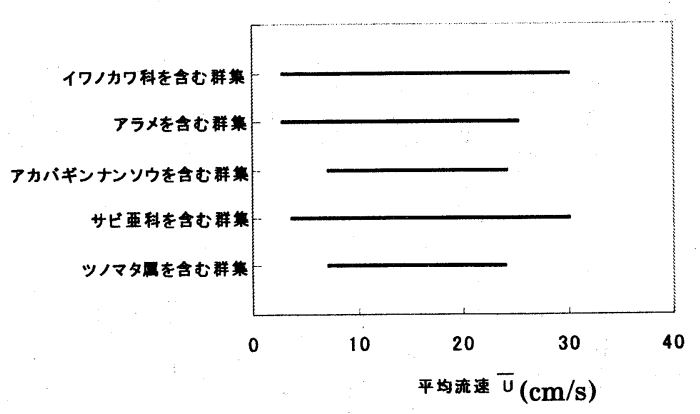

図-6 平均流速と主要群集構成海藻の関倸

\section{（c）流速の変化に対する各海㩰の被度の分布}

次に、図-6に示した上記 5 種の海藻が群集を構成して いる流速範囲において、各海藻の出現被度の分布状況の 検討を行った。検討グラフを図-7に示す。

この結果、各種の被度の状況をみると、イワノカワ科、 ツノマタ属で平均流速 $7 \mathrm{~cm} / \mathrm{s}$ 付近に多く出現する傾向に

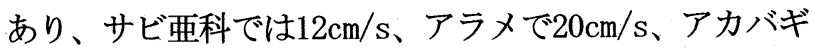
ンナンソウで $24 \mathrm{~cm} / \mathrm{s}$ 付近で出現被度が多くなる傾向に あった。この結果、サビ西科やイワノカワ科では群集を 構成する流速範囲が、他の 3 種に比べ広い傾向にあるが、 被度としては遅い流速範囲で多く出現する傾向にあり、 逆に、アラメについては他の 4 種に比べ低い流速範囲で 群集構成する傾向にあるものの、速い流速で多く出現す る傾向がみられた。

（d）人エリーフ上の流速の違いに対する海藻群集の変化 以上の結果をもとに、平均流速に対する各海藻の生息 可能範囲と被度の変化を定量的に把握するため、平均流 速を $5 \mathrm{~cm} / \mathrm{s}$ 毎に区分し、それぞれの平均流速範囲におけ る各海藻の出現確率について検討を行った。なお、海藻
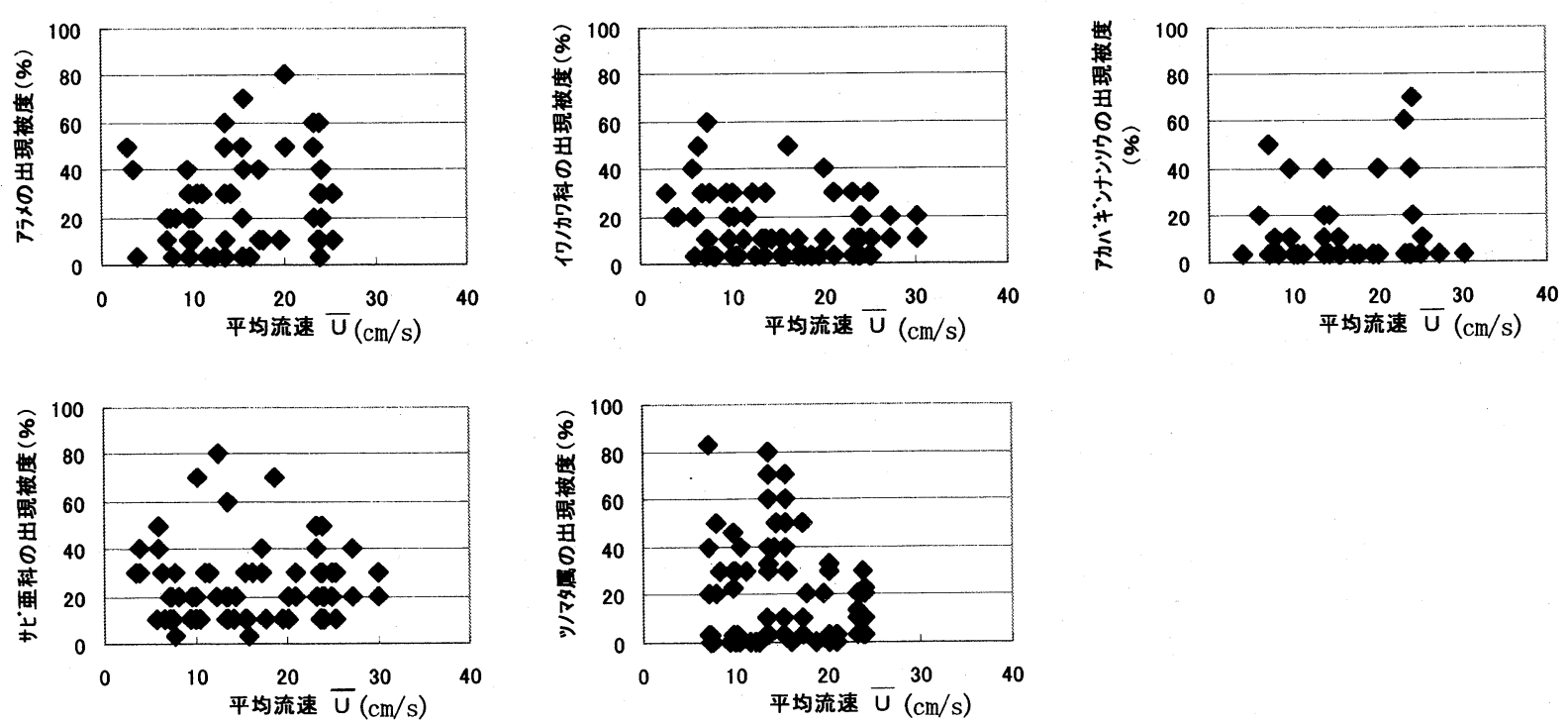

図-7 各群集構成海藻の平均流速と出現被度の関係 

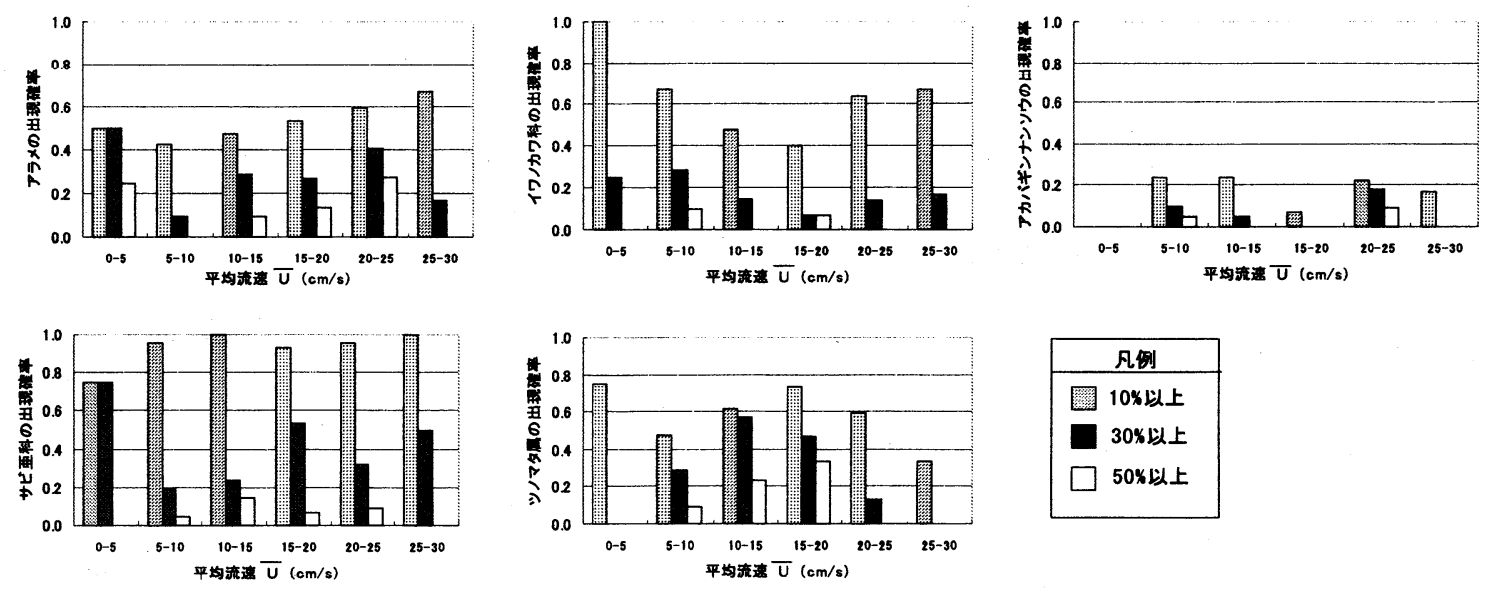

図-8 各群集構成種の出現確率

の出現確率は、上記 5 種の海藻について被度が $10 \%$ 以上 になる確率、30\%以上になる確率、50\%以上になる確率 を計算した。検討結果を図-8に示す。

この結果、被度が10\%以上になる確率では、アカバギ ンナンソウ以外の 4 種で平均流速 $0-30 \mathrm{~cm} / \mathrm{s}$ の範囲で出現 がみられており、アカバギンナンソウ以外の 4 種につい ては、広い流速範囲で生息することが可能であることが 確認された。

次に、被度が $30 \%$ あるいは $50 \%$ となる確率は、平均流 速 $0-5 \mathrm{~cm} / \mathrm{s}$ の範囲で、アラメ、サビ亜科、イワノカワ科 が出現していた。次に、平均流速5 $-30 \mathrm{~cm} / \mathrm{s}$ 範囲では、 アラメ、アカバギンナンソウで $20-25 \mathrm{~cm} / \mathrm{s}$ の早い流速範 囲で高い傾向にあるが、イワノカワ科は5-10cm/s、ツノ マタ属は10-20cm/s、サビ亜科は $15-20 \mathrm{~cm} / \mathrm{s}$ で高い傾向に あり、アラメやアカバギンナンソウに比べて低い傾向に あった。その結果、図-9に示すとおり、平均流速0$5 \mathrm{~cm} / \mathrm{s}$ の低流速区域ではサビ带科、イワノカワ科、アラ メの小群集により構成されているが、平均流速10$20 \mathrm{~cm} / \mathrm{s}$ の範囲ではツノマタ属の群集が増加し、平均流速 $20 \mathrm{~cm} / \mathrm{s}$ 以上の範囲になると、ツノマタ属が減少しサビ亜 科、アラメの群集が増加する傾向にあり、人工リーフ上 の流速の違いが、生息する海藻の群集を変化させている 可能性が考えられた。

以上のとおり、人工リーフ上の海藻と流速との関係を 検討した結果、人工リーフの広い範囲で、施工後（海藻 の付着基質設置後）始めは珪藻綱などが付着し、その後、 1 年生小型海藻、多年生小型海藻と生息寸る海藻が変化 するが、4年程度経過した箇所に出現する海藻は、流速 の違いにより繁茂する海藻が異なる可能性が考えられた。

\section{5. おわりに}

今回の海藻群集を構成した種は、アラメを除いて全て 小型の海藻であり、流れによる影響がアラメに比べて小 さいと想定される海藻であった。しかし、アラメはこれ ら 4 種の海藻より速い流速範囲で多く生息する結果と

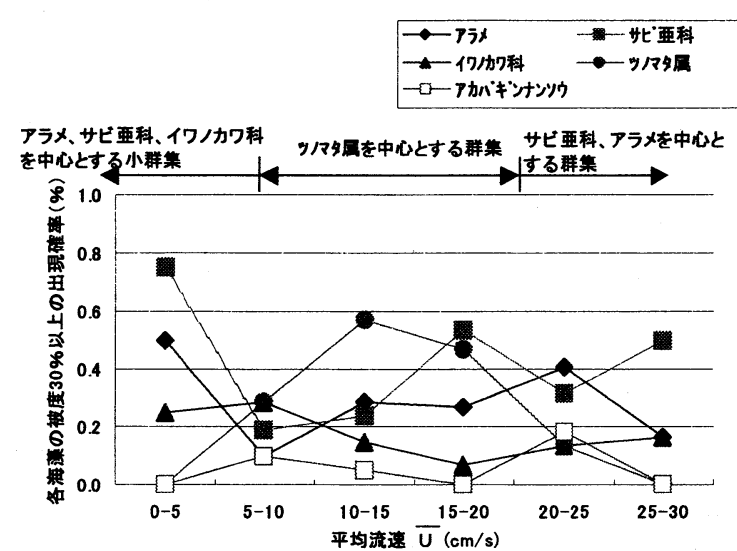

図-9 平均流速に対する被度 $30 \%$ 以上出現する確率

なっており、アラメの形状が速い流速範囲で生息しやす いことなどが考えられる。よって、今後アラメの形状等 と流れの関係についてより詳細な検討が必要と考えられ た。

\section{参考文献}

1) 井上公人 ・ 田中 仁・西村 修・馬場 聡 : 人エリーフに生 息する海藻の遷移, 環境工学研究論文集, 第37巻, pp. 379387, 2000.

2) 建設省河川局防災・海岸課海岸室 : 海岸域生物環境調查又 ニュアル (試行案)，161pp., 1996.

3) 新崎盛敏 : 原色海藻検索図鑑，北隆館，217pp., 1964.

4) 片田 実-今野敏德: 植物生態学講座 4 , 朝倉書店, 306pp., 1977.

5）合田良實：港湾構造物の耐波設計，鹿島出版会，pp. 57, 1997.

6) 西村仁嗣 : 海浜循環流の数值シシュレーション，第29回海岸工学講 演論文集，pp. 333-337， 1982.

7) Longuet-Higgins,M.S. : Longshore currents generated by obliquely incident wave, J. Goephys. Res., Vol.75, No.33, pp.6778-6789, 1970.

8) 木元新作 : 生態学研究法講座 14 , 共立出版, $192 \mathrm{pp} ., 1976$.

(2001.10.1受付) 